\title{
Editorial \\ TWEAK: a novel biomarker for lupus nephritis?
}

Neeraj Dhaun ${ }^{1}$ and David C Kluth ${ }^{2}$

\begin{abstract}
${ }^{1}$ Clinical Pharmacology Unit, University of Edinburgh, The Queen's Medical Research Institute, 47 Little France Crescent, Edinburgh EH16 4TJ, UK
${ }^{2}$ Centre for Inflammation Research, University of Edinburgh, The Queen's Medical Research Institute, 47 Little France Crescent, Edinburgh EH16 4TJ, UK
\end{abstract}

Corresponding author: Neeraj Dhaun, bean.dhaun@ed.ac.uk

See related research by Schwartz et al., http://arthritis-research.com/content/11/5/R143

Published: 17 November 2009

This article is online at http://arthritis-research.com/content/11/6/133

(C) 2009 BioMed Central Ltd
Arthritis Research \& Therapy 2009, 11:133 (doi:10.1186/ar2846)

substantial renal tissue damage can occur before function is impaired to a detectable extent [4]. Renal biopsy remains the gold standard for assessment of LN disease activity. Serial renal biopsies, however, are not appropriate in clinical practice. There is therefore an important unmet need for biomarkers that discriminate disease severity, assess response to therapy and more accurately predict disease relapses. These biomarkers would allow early implementation of appropriate treatments with the hope of preventing disease progression.

TNF-like weak inducer of apoptosis (TWEAK) is a multifunctional cytokine that is a member of the TNF superfamily and binds to its cognate receptor Fn14. It signals through the NF- $\mathrm{KB}$ pathway and can stimulate a wide array of cytokines, chemokines and cell adhesion molecules. TWEAK plays a role in tissue inflammation, repair and regeneration in many diseases, including SLE [5]. In a mouse model of SLE, the absence of Fn14 or treatment with an anti-TWEAK antibody reduces renal inflammation and severity of proteinuria [6]. Similarly, inhibition of TWEAK in models of multiple sclerosis, rheumatoid arthritis and ischaemic injury has antiinflammatory effects [5].

In the current paper by Schwartz and colleagues, TWEAK was assessed as a biomarker for $L N$ in both cross-sectional and longitudinal studies. In the former, UTWEAK was elevated in subjects with $L N$ at diagnosis compared with those with SLE but no renal disease, and correlated with the degree of clinical disease activity as measured using a standard activity index. This distinction remained true when corrected for both renal function and SLE disease severity. Those patients with LN, however, had UTWEAK values that overlapped with those from SLE subjects without $L N$, as well

$\mathrm{LN}=$ lupus nephritis; $\mathrm{NF}=$ nuclear factor; $\mathrm{SLE}=$ systemic lupus erythematosus; TNF $=$ tumour necrosis factor; TWEAK $=$ TNF-like weak inducer of apoptosis; UTWEAK = urinary TNF-like weak inducer of apoptosis. 
Table 1

\begin{tabular}{|c|c|c|c|}
\hline Urinary marker & Function & Patient cohort & Main findings \\
\hline $\begin{array}{l}\text { Monocyte chemoattractant } \\
\text { protein-1 (MCP-1) [7] }\end{array}$ & $\begin{array}{l}\text { Chemokine, particularly for } \\
\text { monocyte }\end{array}$ & 25 adult patients with renal flare & $\begin{array}{l}\text { Urinary MCP- } 1 \text { predicted flare by } 2 \text { to } \\
4 \text { months and slowly fell following } \\
\text { treatment }\end{array}$ \\
\hline $\begin{array}{l}\text { Neutrophil gelatinase-associated } \\
\text { lipocalin (NGAL) [8] }\end{array}$ & $\begin{array}{l}\text { Antimicrobial protein and } \\
\text { siderophore }\end{array}$ & $\begin{array}{l}35 \text { paediatric patients, } 18 \text { with } \\
\text { renal disease }\end{array}$ & $\begin{array}{l}\text { Urinary NGAL associated with renal } \\
\text { disease and chronic damage ( } 90 \% \\
\text { sensitivity). Not as strongly associated } \\
\text { in adult patients }\end{array}$ \\
\hline Hepcidin [9] & $\begin{array}{l}\text { Antimicrobial protein and } \\
\text { siderophore }\end{array}$ & $\begin{array}{l}19 \text { adult patients with renal flares. } \\
\text { Urine assessed using proteomics }\end{array}$ & $\begin{array}{l}\text { Urinary hepcidin predicted flare by } \\
4 \text { months and reduced with treatment }\end{array}$ \\
\hline Endothelin-1 (ET-1) [10] & $\begin{array}{l}\text { Vasoconstrictor, with roles in } \\
\text { inflammation and fibrosis }\end{array}$ & $\begin{array}{l}10 \text { adult patients with lupus } \\
\text { nephritis }\end{array}$ & $\begin{array}{l}\text { Fractional excretion of ET-1 correlated } \\
\text { with lupus nephritis and fell with } \\
\text { treatment }\end{array}$ \\
\hline $\begin{array}{l}\text { TNF-like weak inducer of } \\
\text { apoptosis (TWEAK) [1] }\end{array}$ & $\begin{array}{l}\text { Proinflammatory cytokine. } \\
\text { May be involved in resolution } \\
\text { of injury }\end{array}$ & $\begin{array}{l}30 \text { patients with lupus nephritis, } \\
13 \text { lupus nephritis patients in a } \\
\text { longitudinal study }\end{array}$ & $\begin{array}{l}\text { Urinary TWEAK correlated with lupus } \\
\text { nephritis disease activity and fell with } \\
\text { treatment }\end{array}$ \\
\hline
\end{tabular}

as those with rheumatoid arthritis, osteoarthritis and other non-inflammatory renal disease - suggesting the lack of specificity of UTWEAK for LN. Furthermore, all subjects studied had a good level of renal function (serum creatinine $\sim 1 \mathrm{mg} / \mathrm{dl}$ ), and so it remains unclear how UTWEAK may be affected by more significant declines in renal function. This may be important because the authors state that serum TWEAK did not show any of the associations described, suggesting that UTWEAK may be of renal origin. Unfortunately, UTWEAK did not discriminate between different LN histological classes. This is a common problem in LN biomarker studies. The problem probably relates to the small number of subjects studied who are then subgrouped into a number of histological classes, the inherent sampling error associated with renal biopsy, and the lack of a clear system to assess inflammatory disease activity at the tissue level. In the longitudinal study, UTWEAK levels peaked at time of diagnosis of a LN flare and fell with its treatment, taking 4 months to return to preflare levels. Unfortunately, the small rise in UTWEAK prior to the disease flare does not appear to have predictive value.

The work of Schwartz and colleagues complements a number of recent studies that have attempted to find new biomarkers for LN. In most of these studies the three main aims have been to assess the severity of renal inflammation, to monitor response to immunosuppressive therapy and to predict flare of disease. A number of promising candidates have been identified and these are summarised in Table 1. All of these potential biomarkers are more sensitive at identifying renal inflammation than the standard assays (serum creatinine, proteinuria, double-stranded DNA, complement). There remain, however, common weaknesses. No potential biomarkers have been correlated with the histological class of
LN or the severity of tissue injury; as such, they cannot supplant repeat renal biopsies. None of the potential biomarkers are specific for LN, as they can be upregulated in other forms of renal inflammation and may increase as renal function declines. Finally, no long-term studies using large cohorts of LN patients have been performed.

It remains unlikely that a single urinary biomarker will provide sufficient information to determine diagnosis, response to therapy and disease activity in LN. The scene is now set, however, for studies in which multiple markers may be compared and correlated with LN histology, disease progression and recurrence. This research will become of increasing importance as treatment for $\mathrm{LN}$ becomes more tailored to the individual.

\section{Competing interests}

The authors declare that they have no competing interests.

\section{References}

1. Schwartz N, Rubinstein T, Burkly LC, Collins CE, Blanco I, Su L, Hojaili B, Mackay M, Aranow C, Stohl W, Rovin BH, Michaelson JS, Putterman C: Urinary TWEAK as a biomarker of lupus nephritis: a multicenter cohort study. Arthritis Res Ther 2009, 11:R143.

2. Seshan SV, Jennette JC: Renal disease in systemic lupus erythematosus with emphasis on classification of lupus glomerulonephritis: advances and implications. Arch Pathol Lab Med 2009, 133:233-248.

3. Jayne D, Rasmussen N, Andrassy K, Bacon P, Tervaert JW, Dadoniené J, Ekstrand A, Gaskin G, Gregorini G, de Groot K, Gross W, Hagen EC, Mirapeix E, Pettersson E, Siegert C, Sinico A, Tesar V, Westman K, Pusey C; European Vasculitis Study Group: A randomized trial of maintenance therapy for vasculitis associated with antineutrophil cytoplasmic autoantibodies. N Engl J Med 2003, 349:36-44.

4. Hewitt SM, Dear J, Star RA: Discovery of protein biomarkers for renal diseases. J Am Soc Nephrol 2004, 15:1677-1689.

5. Winkles JA: The TWEAK-Fn14 cytokine-receptor axis: discov- 
ery, biology and therapeutic targeting. Nat Rev Drug Discov 2008, 7:411-425.

6. Zhao Z, Burkly LC, Campbell S, Schwartz N, Molano A, Choudhury A, Eisenberg RA, Michaelson JS, Putterman C: TWEAK/ Fn14 interactions are instrumental in the pathogenesis of nephritis in the chronic graft-versus-host model of systemic lupus erythematosus. J Immunol 2007, 179:7949-7958.

7. Rovin BH, Song H, Birmingham DJ, Hebert LA, Yu CY, Nagaraja $\mathrm{HN}$ : Urine chemokines as biomarkers of human systemic lupus erythematosus activity. J Am Soc Nephrol 2005, 16:467473.

8. Brunner HI, Mueller M, Rutherford C, Passo MH, Witte D, Grom A, Mishra J, Devarajan P: Urinary neutrophil gelatinase-associated lipocalin as a biomarker of nephritis in childhood-onset systemic lupus erythematosus. Arthritis Rheum 2006, 54: 2577-2584.

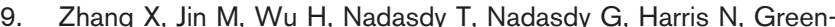
Church K, Nagaraja H, Birmingham DJ, Yu CY, Hebert LA, Rovin $\mathrm{BH}$ : Biomarkers of lupus nephritis determined by serial urine proteomics. Kidney Int 2008, 74:799-807.

10. Dhaun N, Lilitkarntakul P, Macintyre IM, Muilwijk E, Johnston NR, Kluth DC, Webb DJ, Goddard J: Urinary endothelin-1 in chronic kidney disease and as a marker of disease activity in lupus nephritis. Am J Physiol Renal Physiol 2009, 296:1477-1483. 